\title{
PENGARUH HARGA MINYAK BUMI, HARGA BAHAN BAKU PLASTIK TERHADAP RETURN ON ASSET PADA PERUSAHAAN PENGHASIL BAHAN BAKU PLASTIK
}

\author{
Denny Saputera \\ Dennysaputera35@gmail.com \\ Fakultas Ekonomi dan Bisnis Universitas Serang Raya
}

\begin{abstract}
ABSTRAK
Penelitian ini berfokus padapengaruh harga minyak bumi, harga bahan baku plastikterhadap return on assets pada perusahaan penghasil bahan baku plastik di indonesia. Penelitian ini bertujuan untuk mengetahui growth return on asset yang tinggi membuat perusahaan penghasil bahan baku plastik akan mendapatkan keuntungan yang maksimal dari penggunaan atau perputaran aset yang dimiliki. Jika dihubungkan secara langsung kaitan antara growth harga minyak bumi, growth industri plastikdan growth return on asset memiliki keterkaitan yaitu bahan baku plastik berasal dari minyak bumi, dimana harga bahan baku plastik menjadi sangat sensitif terhadap fluktuasi pergerakan harga minyak bumi yang nantinya akan mempengaruhi profitabilitas perusahaan. Variabel Independen yang digunakan adalah Harga Minyak Bumi, Harga Naphtha, Harga Ethylene, Harga Polyethylene, Harga Ethylene Glycol, Harga Polyvinyl Chloride, Harga Propylene dan Harga Polyproylene. Metode analisis yang digunakan yaitu regresi linier berganda dengan menggunakan bantuan software SPSS 20. Hasil penelitin dapat disimpulkan bahwa Harga Ethylene dan Harga Ethylene Glycol memiliki pengaruh terhadap return on assets.
\end{abstract}

Kata kunci: Harga Minyak Bumi, Harga Bahan Baku Plastik, Return on Assets.

\begin{abstract}
This study focuses on the effect of petroleum prices, the price of plastic raw materials on return on assets in companies producing plastic raw materials in Indonesia. This study aims to determine the high growth return on assets, making the companies that produce plastic raw materials will get the maximum benefit from the use or turnover of assets owned. If directly related to the relationship between the growth of petroleum prices, the growth of the plastic industry and growth return on assets has a relationship, namely plastic raw materials derived from petroleum, where the price of plastic raw materials becomes very sensitive to fluctuations in oil price movements which will affect the company's profitability. The Independent Variables used are Petroleum Prices, Naphtha Prices, Ethylene Prices, Polyethylene Prices, Ethylene Glycol Prices, Polyvinyl Chloride Prices, Propylene Prices and Polyproylene Prices. The analytical method used is multiple linear regression using the help of SPSS 20 software. The results of this study can be concluded that Ethylene Prices and Ethylene Glycol Prices have an influence on return on assets.
\end{abstract}

Keywords: Oil Price, Plastic Raw Material Price, Return on Assets

\section{PENDAHULUAN}

Kinerja keuangan suatu perusahaan dapat diartikan sebagai prospek masa masa depan, pertumbuhan potensi perkembangan yang baik bagi perusahaan. Informasi kinerja 
keuangan diperlukan untuk menilai perubahan potensial sumber daya ekonomi,yang dikendalikan dimasa depan dan untuk memprediksi kapasitas produksi dari sumber daya yang ada (Barlian, 2003). Sedangkan laporan keuanganyang telah dianalisis sangat diperlukan pemimpin dalamsebuah perusahaan ataumanajemen untuk dijadikan sebagaialatpengambilan keputusan lebih lanjut untuk masayang akan datang dan sebagai bahan analisis bagi para investor untuk menanamkan sahamnya.

Return On Asset merupakan salah satuindikator untuk engetahui kinerja keuangan perusahaan dan merupakan rasio profitabilitas yang digunakan untuk mengukur efektivitas perusahaan didalam menghasilkan keuntungan dengan memanfaatkan total aktiva yang dimilikinya dengan Return On Asset yang mewakili rasio profitabilitas perusahaan, alasanya bahwa rasio ini digunakan untuk melihat sejauh mana investasi telah ditanamkan mampu memberikan pengembalian keuntungan di masa depan sesuai dengan yang diharapkan berdasarkan aset yang dimiliki (Fahmi, 2013).

Di Indonesia sebagian besar perekonomiannya mengandalkan sektor migas. Minyak bumi merupakan Input vital dalam proses produksi industri, terutama untuk menghasilkan listrik, menjalankan mesin pruduksi dan mengangkut hasil dari produksi, yang paling utama adalah minyak bumi adalah penggerak perekonomian bagi pembangunan ekonomi dan sosial yang berkelanjutan. Salah satu industri yang berkaitan erat dengan industri migas adalah industri petrokimia.

Beberapa ahli statistik telah menyatakan bahwa terdapat korelasi $80 \%$ antara minyak bumi dan bahan baku petrokimia, yang di sektor hilirnya merupakan bahan baku utama dalam produksi produk akhir plastik (Masih et al, 2014). Sebagai gambaran saat ini perusahaan petrokimia di Indonesia yang memproduksi bahan baku naphtha dan ethylene adalah PT Chandra Asri Petrochemical Tbk (TPIA) akan menikmati keuntungan saat harga minyak dunia turun karena perusahaan bisa membeli bahan baku dengan jumlah yang lebih banyak, dan menjualnya dengan harga yang tetap tinggi (Miyarso,2016). Spread harga minyak bumi, naphtha dan ethylene merupakan indikator keuntungan TPIA sebagai penghasil naphtha dan ethylene (Aprillia, 2016).

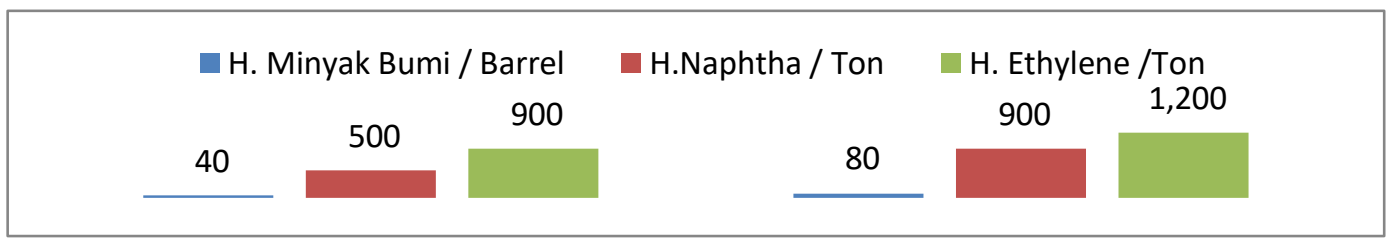

\section{Grafik 1 : Spread Harga Minyak Bumi, Naphtha dan Ethylene.}

Sumber : Budiono, 2015 (data diolah)

Menurut Budiono (2015) di tahun 2015 harga rata-rata minyak bumi US\$ 40 per barrel, maka harga naphtha bisa turun dikisaran US\$ 500 - US\$ 600 per ton. Jika dibandingkan dengan tahun 2014, pada saat harga minyak dunia dengan rata-rata di US\$ 80 per barrel, harga jual naphtha dibanderol US\$ 900 per ton. Sementara untuk harga Ethylene saat harga minyak bumi turun di tahun 2014 dengan harga rata-rata minyak bumi US\$ 40 per barrel dibanderol di kisaran US\$ 900 per ton, lebih rendah dari harga tahun 2014 yang masih di sekitaran US\$ 1.000 per ton. Dari grafik 1 diatas bahwa spread atau 
korelasi dari Growth minyak bumi sangat mempengaruhi turunannya yaitu berupa bahan baku plastik.

Turunan industri bahan baku plastik yang berasal dari minyak bumi saat ini yang industrinya sebagian besar masih berada di sektor hulu antara lain industri olefin, aromatic, ethylene, propylene, butadiene, benzene, toluene, dan xylene. Begitu banyak turunannya secara langsung berupa plastik, bahan sintesis, bahan kimia, pestisida dan lain-lain. Untuk turunan dari produk ethylene dan propylene sebagian sudah dapat diproduksi di Indonesia dan sebagian masih belum dikembangkan. Selanjutnya turunan dari produk ethylene dan propylene ini pada sektor hilirnya digunakan untuk pembuatan plastik.

Tabel 1 : Growth Harga Minyak Bumi, Growth Industri Plastik dan Average ROAPerusahaan Penghasil Bahan Baku Plastik di Indonesia

\begin{tabular}{rrrrrrr}
\hline & $\mathbf{2 0 1 1}$ & $\mathbf{2 0 1 2}$ & $\mathbf{2 0 1 3}$ & $\mathbf{2 0 1 4}$ & $\mathbf{2 0 1 5}$ & \multicolumn{2}{c}{$\mathbf{2 0 1 6}$} \\
\hline Harga Minyak Bumi & 94,01 & 87,96 & 97,34 & 73,16 & 41,95 & 49,14 \\
\hline Pertumbuhan Industri Plastik & 3,80 & 4,02 & 4,43 & 4,85 & 5,07 & 5,35 \\
\hline Average ROA & 3,05 & 0,26 & 2,62 & 3,38 & 3,45 & 6,45 \\
\hline
\end{tabular}

Sumber : Data Diolah

Berdasarkan dari tabel 1 diatas dapat dilihat bahwa growth industri plastik tiap tahunnya meningkat, tetapi tidak diiringi oleh rata-rata growthReturn On Asset perusahaan penghasil bahan baku plastik di tahun 2012 rata-rata growthReturn On Asset perusahaan penghasil bahan baku plastik mengalami penurunan dibandingkan dengan tahun 2011. Untuk Growth harga minyak bumi juga mengalami fluktuasi tiap tahunya. Hal ini mengindikasikan bahwa tren peningkatan growth industri plastik yang didapat oleh perusahaan penghasil bahan baku plastik lebih kecil dibandingkan dengan growthReturn On Asset yang dimilik oleh perusahaan penghasil bahan baku plastik. Fenomena ini menjadi perhatian untuk meneliti lebih lanjut mengenai naik turunnya profitabilitas perusahaan penghasil bahan baku plastik yang diproksikan dengan Return On Asset.

Jika dihubungkan secara langsung kaitan antara growth harga minyak bumi, growth industri plastikdan growth return on asset memiliki keterkaitan yaitu bahan baku plastik berasal dari minyak bumi, dimana harga bahan baku plastik menjadi sangat sensitif terhadap fluktuasi pergerakan harga minyak bumi yang nantinya akan mempengaruhi profitabilitas perusahaan. Growth Return On Asset yang tinggi membuat perusahaan penghasil bahan baku plastik akan mendapatkan keuntungan yang maksimal dari penggunaan atau perputaran aset yang dimiliki, dimana investasi yang telah ditanamkan dapat atau mampu memberikan pengembalian keuntungan sesuai dengan yang diharapkan berdasarkan aset yang dimiliki berupa pertumbuhan profitabilitas

Berdasarkan penjelasan diatas tentang harga minyak bumi, dan bahan baku Petrokimia sebagai hulunya menghasilkan Naphtha, Ethylene dan Propylene kemudian dihilirnya menghasilkan bahan baku plastik berupa Polyethylene, Ethylene Glycol, Polyvinyl Chloride dan Polyproylene serta Return On Assets, maka dari penelitian ini menggunakanvariabel Harga Minyak Bumi, Harga Naphtha, Harga Ethylene, Harga Polyethylene, Harga Ethylene Glycol, Harga Polyvinyl Chloride, Harga Propylene dan 
Harga Polyproylene, ke delapan variabel tersebut merupakan hal yang sangat erat dalam industri plastik.

Penelitian Xu (2015), Basha (2014) meneliti tentang harga minyak terhadap profitabilitas hasilnya berbeda yaitu hubungan harga minyak terhadap profitabilitas return on assets berpengaruh signifikan. Penelitian tersebut sejalan dengan(bayu, 2015) bahwaminyak bumi adalah adalah sebagai penggerak perekonomian bagi pembangunan ekonomi dan sosial yang berkelanjutan, dengan demikian dampak dari growth minyak bumi tercermin pada kenaikan harga dari semua barang konsumsi, kenaikan ongkos angkut, kenaikan dasar listrik yang sangat berkaitan erat dengan growthindustri bahan baku plastik.

\section{LANDASAN TEORI DAN PENGEMBANGAN HIPOTESIS}

\section{Pengaruh Harga Minyak Bumi Terhadap Return On Assets.}

Hasil penelitian ini menunjukkan bahwa harga minyak bumi memiliki hubungan negatif dan tidak memiliki pengaruh signifikanterhadap Return On Assets. Hasil dari penelitian ini tidak sejalan dengan penelitian sebelumnya yaitu Xu (2015), Basha (2014) meneliti tentang Harga Minyak Terhadap Profitabilitas hasilnya berbeda yaitu hubungan Harga Minyak Terhadap Return On Assets berpengaruh positif signifikan.

Industri plastik di Indonesia baik perusahaan yang dikelola oleh industri berbasis hulu, antara maupun hilir tentunya akan meningkatkan kapasitas produksi untuk memenuhi pertumbuhan permintaan didalam negeri dengan tujuan meminimalisir Impor bahan baku plastik. Menambah kapasitas produksi tentunya akan menambah aset berupa mesin, bangunan dan lain-lain berarti total aset pun akan bertambah (naik), yang juga akan berdampak Net Income yang didapatkan juga otomatis akan bertambah yang akan berpengaruh terhadap persentase Return On Assets TPIA jika minyak bumi tersedia dapat mencukupi kebutuhan dalam negeri dan terusmeminimalisir impor minyak bumi

H1 : Harga Minyak Bumi tidak memiliki pengaruh signifikanterhadap Return On Assets.

\section{Pengaruh Harga NaphthaTerhadap Return On Assets..}

Hasil penelitian menunjukkan bahwa harga naphthatidak memiliki pengaruh signifikanterhadap Return On Asset. Hasil dari penelitian ini tidak sejalan dengan penelitian sebelumnya yaitu Ray (2014), Chiranjeev(2010), Kwon (2016) meneliti tentang Harga Naphtha Terhadap Return On Assets Industri Plastik hasilnya berbeda yaitu hubungan Harga NaphthaReturn On Assets berpengaruh positif signifikan, dikarenakan naphtha sebagai input utama dalam industri plastik setelah minyak bumi, produksi awal naphtha di Indonesia baru di mulai tahun 2013 yaitu diproduksi oleh TPIA dimana kebutuhan Naphtha di Indonesia sangat bergantung oleh produksi TPIA. TPIA adalah memiliki satu-satunya pabrik Naphtha Cracker di Indonesia menandatangani kontrak kerjasama rekayasa pengadaan dan konstruksipembangunan penambahan kapasitas produksi dan kapasitasnya meningkat sebesar 43\%(TPIA, 2016).

Naphtha adalah bahan baku utama dalam Industri Petrokimia terutama sebagai bahan baku utama untuk menghasilkan plastik yang awal mulanya berasal dari minyak bumi dan 
naphtha sebagai turunan langsung akan menghasilkan Ethylene, Propylene dan lainnya. Harga Naphtha sangat tergantung dari fluktuasi harga Minyak Bumi. Jika harga minyak bumi naik harga naphtha juga akan naik begitu juga sebaliknya.

$\mathrm{H} 2$ : Harga naphthatidak memiliki pengaruh signifikanterhadap return on asset

\section{Pengaruh Harga EthyleneTerhadap Return On Assets..}

Hasil penelitian ini menunjukkan bahwa Harga Ethylenememilikihubungan negatif dan memiliki pengaruhsignifikan terhadap Return On Assets. Hasil dari penelitian ini tsejalan dengan penelitian sebelumnya yaituRay (2014) meneliti Harga Ethylene Terhadap Return On Assets Industri Plastik hasilnya berbeda yaitu Harga Ethylene Terhadap Return On Assets berpengaruh positif signifikan

Harga Ethylene memiliki pengaruh negatif dan signifikan terhadap Return On Assets dikarenakan Ethylene merupakan bahan baku paling penting dalam industri petrokimia dan plastik. Sekitar 130 juta ton Ethylene diproses di seluruh dunia pada tahun 2013. aplikasi langsungnya digunakan untuk produksi plastik. Kapasitas produksi Ethylene yang bertambah dari 600KTA ke 860KTA membuat TPIA sebagai satu-satunya perusahaan yang memproduksi Ethylene di Indonesia menjadi perusahaan terbesar ke 5 di Asia Tenggara yang memproduksi polyolefins (TPIA, 2015). Dengan bertambahnya kapasitas produksi Ethylene, menunjukan bahwa dari aset yang dipergunakan memproduksi Ethylene yang akan berpengaruh terhadap Net Income, terntunya akan mempengaruhi Return On Assets. Bertambahnya kapasitas produksi setelah ekspansi di tahun 2015 dengan kapasitas 860KTA dengan total permintaan akan Ethylene didalam negeri sebesar 430KTA TPIA surplus430KTA yang menyimpan cadangan 50\% dari kapasitas didalam negeri.

H3 : Harga Ethylene memiliki pengaruh negatif signifikanterhadap return on asset.

\section{Pengaruh Harga PolyethyleneTerhadap Return On Assets..}

Hasil penelitian menunjukkan bahwa Harga Polyethylene memilikihubungan positif dan tidak memilik pengaruh signifikan terhadap Return On Assets. Hasil dari penelitian ini tidak sejalan dengan penelitian sebelumnya yaitu Titov (2014), Malikane (2000) dan Koplan (2005) meneliti tentang Harga PolyethyleneTerhadap Return On Assets Industri Plastik tetapi hasilnya berbeda yaitu hubungan Harga PolyethyleneTerhadap Return On Assets berpengaruh positif signifikandikarenakan dipenelitian ini perusahaan yang menghasilkan Polyethylene yaitu TPIA dan FPNI yang merupakan dua dari empat perusahaan penghasil Polyethylene di Indonesia selain PT. Pertamina UP III Plaju dan PT. Polytama.

Permintaan polyethylene pada 2015 mencapai 1,4 juta ton dengan konsumsi plastik 19kilogram per kapita, 800.000 ton per tahun diproduksi oleh TPIA, FPNI, PT. Pertamina UP III dan PT. Polytama, sisanya masih diimpor. Seiring merosotnya harga naphtha, ethylene di tahun 2015 harga polyethylene ikut turun yang sampai sekarang yang masih bergantung pada impor. Karena produksi Polyethylene di Indonesia masih tergantung Impor, dan Harga Polyethylene pada umumnya mengikuti tren harga minyak bumi dan bervariasi sesuai dengan kondisi pasar minyak bumi. 
H4 : Harga Polyethylene memiliki pengaruh positif tidak signifikanterhadap return on asset.

\section{Pengaruh Harga Ethylene GlycolTerhadap Return On Assets..}

Hasil penelitian menunjukkan bahwa Harga Ethylene Glycolmemiliki hubungan negatif dan memiliki pengaruh signifikan terhadap Return On Assets. Hasil dari penelitian ini sejalan dengan penelitian sebelumnya yaitu Chatterjee (2011) juga meneliti tentang Harga Ethylene GlycolTerhadap Return On Assets Industri Plastik tetapi hasilnya sama yaitu hubungan Harga Ethylene Glycol Terhadap Return On Assets berpengaruh negatif signifikan dikarenakan motode efisiensi dan pengunaan biaya yang efektif.

Harga Ethylene Glycol memiliki pengaruh negatif dan signifikan terhadap Return On Assets dikarenakan Ethylene Glycol digunakan sebagai bahan baku Botol minuman berkarbonasi, stoples selai kacang, film plastik, kemasan microwave yang di Indonesia sangat tergantung pada AMFG yang dimasukan sebagai objek dalam penelitian ini. Ethylene Glycol adalah polimerisasi dari Ethylene sebagai bahan bakunya yang dari tahun 2013 ke 2015 kapasitas produksinya terus bertambah (216KTA) dengan penambahan kapasitas menunjukan bahwa dari total aset dari penggunaan atau perputaran aset yang ditanamkan pasca ekspansi.

H5 : Harga Ethylene Glycol memiliki pengaruh negatif signifikan terhadap return on asset.

\section{Pengaruh Harga Polyvinyl ChlorideTerhadap Return On Assets. .}

Hasil penelitian menunjukkan bahwa harga polyvinyl chloridememiliki hubungan positif dan tidak memilik pengaruh signifikan terhadap Return On AssetsHasil dari penelitian ini sejalan dengan penelitian sebelumnya yaitu Malikane (2000) juga meneliti tentang Harga PVC Terhadap Return On Assets Industri Plastik tetapi hasilnya berbeda yaitu hubungan Harga Polyethylene, Harga PVC Terhadap Return On Assets berpengaruh positif signifikan, dikarenakan di Indonesia PVC di produksi oleh empat perusahaan yaitu AMCG, PT. Standard Toyo Polymer, PT. Satomo Indovyl Polymer, dan PT. Eastern. Industri PVC memiliki ketergantungan pasokan ethylene pada pasar internasional karena sebagian besar kebutuhannya masih diimpor.

Bahan baku untuk menghasilkan PVC yaitu minyak bumi masih berasal dari impor, Menambah kapasitas produksi dengan tujuan meminimalisir impor bahan baku tentunya akan berdampak pada penurunan Net Income yang didapatkan dan otomatis dengan penurunan Net Income maka persentase Return On Assets pun juga akan mengalami penurunan oleh karena itu harga PVC memiliki hubungan positif namun tidak memiliki pengaruh signifikanterhadap Return On Assets.

H6 : Harga polyvinyl chloridememiliki pengaruhpositif tidak signifikan terhadap return on asset.

\section{Pengaruh Harga PropyleneTerhadap Return On Assets..}

Hasil penelitian menunjukkan bahwa Harga Propylenememiliki hubungan positif dan tidak memilik pengaruh signifikan terhadap Return On Assets. Hasil dari penelitian ini tidak sejalan dengan penelitian sebelumnya yaitu Titov (2014) juga meneliti tentang Harga 
PropyleneTerhadap Return On Assets Industri Plastik tetapi hasilnya berbeda yaitu hubungan Harga PropyleneTerhadap Return On Assets berpengaruh positif signifikan, dikarenakan bahan baku dari propylene adalah naphtha di indonesia masih bergantung pada impor, di dalam negeri propylene di produksi oleh TPIA dan PT. Pertamina UP III. Kapasitas Propylene TPIA tahun 2016 yaitu 320KTA sedangkan permintan di dalam negeri 480KTA, dengan penambahan produksi Propylene oleh PT. Pertamina UP III pun permintaan di masih belum tercukupi, solusinya adalah penambahan kapasitas produksi Propylene didalam negeri, menambah kapasitas produksi tentunya akan berdampak pada penurunan Net Income yang didapatkan dan membuat permintaan didalam negeri akan tercukupi.

Dengan penurunan Net Income maka Return On Assets pun juga akan mengalami penurunan walaupun tidak signifikan, oleh karena itu Harga Propylene memiliki hubungan positiftidak memiliki pengaruh signifikanterhadap Return On Assets

H7 : Harga Propylene memiliki pengaruh positif tidak signifikan terhadap return on asset.

\section{Pengaruh Harga PolyproyleneTerhadap Return On Assets..}

Hasil penelitian menunjukkan bahwa HargaPolyproylene memiliki hubungan positif dan tidak memilik pengaruh signifikan terhadap Return On Assets. Hasil dari penelitian ini tidak sejalan dengan penelitian sebelumnya yaitu Titov (2014) harga polypropyleneterhadap return on assets industri plastik tetapi hasilnya berbeda yaitu hubungan harga propylene danharga polypropylene terhadap return on assets berpengaruh positif signifikan, dikarenakan bahan baku dari Polypropylene adalah Propylene yang berasal dari Naphtha di Indonesia bergantung kebutuhannya dari impor, Polypropylen diproduksi oleh tiga perusahaan yaitu TPIA dengan kapasitas 480KTA, PT. Polytama 386KTA dan PT. Pertamina RU VI Balongan dengan 45KTA, total produksi Polyproylene ditahun 2015 sebesar 911KTA. TPIA menguasai produksi sebesar 52,6\%, PT. Polytama $42.3 \%$ dan PT. Pertamina RU VI 5,1\%. Sekitar 50\% permintaan dalam negeri masih tergantung impor.

H8 : Harga Polyproylene memiliki pengaruh positif tidak signifikan terhadap return on asset.

\section{METODE PENELITIAN}

\section{Model Penelitian}

Penelitian ini menggunakan metode penelitian kuantitatif. Metode kuantitatif sendiri menurut Sugiono (2012) adalah metode penelitian yang berlandaskan pada filsafat positivism, digunakan untuk meneliti pada populasi atau sampel tertentu, pengumpulan data mengunakan instrument penelitian, analisa data bersifat kuantitatif/statistik, dengan tujuan untuk menguji hipotesis yang telah di tetapkan, dengan berdasarkan data sekunder.

Pendekatan penelitian ini merupakan penelitian murni/dasar karena bersifat melengkapi penelitian yang dilakukan sebelumnya serta hanya untuk meningkatkan 
pengetahuan. Sehingga sangat dimungkinkan dilakukan penelitian selanjutnya yang lebih mendalam. Dalam penelitian ini data diolah dengan pendekatan kuantitatif yaitu menggunakan data berbentuk angka-angka yang kemudian diolah dengan software statistik.

\section{Variabel Penelitian.}

Menurut Kuncoro (2003) variabel adalah sesuatu yang dapat membedakan atau mengubah nilai.Dalam penelitian ini mengunakan delapan variabel independen, yaitu Harga Minyak Bumi $\left(X_{1}\right)$, Harga Naphtha $\left(X_{2}\right)$, Harga Ethylene $\left(X_{3}\right)$, Harga Polyethylene $\left(X_{4}\right)$, Harga Ethylene Glycol $\left(\mathrm{X}_{5}\right)$, Harga Polyvinyl Chloride $\left(\mathrm{X}_{6}\right)$, Harga Propylene $\left(\mathrm{X}_{7}\right)$ dan Harga Polyproylene $\left(\mathrm{X}_{8}\right)$ serta variabel dependen yaitu ReturnonAssets $(\mathrm{Y})$.

\section{Populasi dan Sampel}

Menurut Soehartono (2012) populasi adalah wilayah generalisasi yang terdiri atas objek / subjek yang mempunyai kualitas dan karakteristik tertentu yang ditetapkan oleh penulis untuk dipelajari dan kemudian hari di tarik kesimpulan. Populasi dalam penelitian ini adalah seluruh data pertumbuhan harga (Minyak Bumi, Naphtha, Ethylene, Polyethylene, Ethylene Glycol, Polyvinyl Chloride, Propylene dan Polyproylene)

Menurut Seohartono (2012) sampel adalah bagian dari jumlah dan karakteristik yang dimiliki oleh populasi atau dengan kata lain sampel adalah bagian dari populasi yang diharapkan dapat mewakili populasi penelitian. Sampel pada penelitian ini adalah sebanyak tiga perusahaan yaituPT Candra Asri Petrochemical Tbk, PT. Lotte Chemical Titan Tbk dan PT. Asahimas Group Tbk.Pengamatan populasi dan sampel dilakulakan secara triwulan (kuarter) selama 6 tahun dari tahun 2011-2016, dengan total 72 sampel.

\section{Teknik Pengumpulan Data.}

Teknik pengumpulan data marupakan cara untuk memperoleh bahan-bahan atau kenyataan yang benar-benar mengungkapkan data-data yang diperlukan dalam suatu penelitian, baik data yang pokok maupun data penunjang. Teknik pengumpulan data dilakukan penulis untuk melengkapi data yang dibutuhkan dalam penelitian adalah dokumentasi yaitu pengumpulan data sekunder yang berupa data-data tertulis dan berhubungan dengan penelitian dari sumber dokumen, buku, laporan instansi dan internet.

\section{Teknik Analisis Data.}

Menurut Gujarati (2006) secara umum analisis regresi pada dasrnya adalah studi mengenai ketergantungan variabel terikat dengan varaibel bebas, dengan tujuan untuk mengestimasi dan memprediksi rata-rata populasi atau nilai rata-rata varaibel terikat berdasarkan nilai dari varaibel bebas yang diketahui.

Penelitian ini harus memenuhi asumsi-asumsi dasar yaitu uji normalitas, uji multikolinearitas, uji autokorelasi, dan uji heteriskesdatisitas. Penelitian ini menguji hipotesis dengan analisis koefisien determinasi, uji F dan uji T. Semua pengujian dalam penelitian ini dilakukan dengan bantuan IBM SPSS Statistic Version 20. SPSS adalah 
software yang digunakan untuk menganalisis statistik. SPSS adalah kependekan dari Statistical Package for the Social Science (Wahana Komputer, 2014).

\section{HASIL PENELITIAN DAN PEMBAHASAN}

\section{Statistik Deskriptif}

Berdasarkan data deskriptif yang diperoleh sejak tahun 2011 sampai dengan tahun 2016 disajikan dalam data triwulan (kuarter) yang meliputi nilai minimum, nilai maximum, nilai rata-rata (mean) dan standar penyimpangan baku (std. deviation) dari variabel independen yang terdiri dari pertumbuhan Harga Minyak Bumi $\left(\mathrm{X}_{1}\right)$, Harga Naphtha $\left(\mathrm{X}_{2}\right)$, Harga Ethylene $\left(\mathrm{X}_{3}\right)$, Harga Polyethylene $\left(\mathrm{X}_{4}\right)$, Harga Ethylene Glycol $\left(\mathrm{X}_{5}\right)$, Harga Polyvinyl Chloride $\left(\mathrm{X}_{6}\right)$, Harga Propylene $\left(\mathrm{X}_{7}\right)$ dan Harga Polyproylene $\left(\mathrm{X}_{8}\right)$ serta variabel dependen Return On Assets (Y)

Tabel 2. Statistik Deskriptif

\begin{tabular}{lrrrrr}
\hline Variabel & N & Minimum & Maximum & \multicolumn{1}{c}{$\begin{array}{c}\text { Mean } \\
\text { Deviation }\end{array}$} \\
\hline Growth.H.MinyakBumi & 72 & $-33,65$ & 36,84 & $-1,0792$ & 14,99221 \\
Growth.H.Naphtha & 72 & $-29,11$ & 23,53 & $-1,0079$ & 14,05662 \\
Growth.H.Ethylene & 72 & $-23,05$ & 40,65 & 1,0533 & 14,32395 \\
Growth.H.Polyethylene & 72 & $-21,75$ & 21,13 &, 0833 & 9,29788 \\
Growth.H.EthyleneGlycol & 72 & $-21,39$ & 38,71 &, 2925 & 13,71452 \\
Growth.H.PolyvinylChlorid & 72 & $-20,33$ & 26,86 &, 1875 & 11,16668 \\
Growth.H.Propylene & 72 & $-28,04$ & 24,53 &,- 2433 & 13,79471 \\
Growth.H.Polypropylene & 72 & $-25,85$ & 13,77 &,- 6754 & 8,57571 \\
ROA & 72 & $-346,18$ & 1720,18 & 71,8992 & 284,30066 \\
\hline
\end{tabular}

Sumber : Output SPSS 20

\section{Uji Normalitas}

Normalitas data merupakan suatu asumsi terpenting dalam statistika parametric, sehingga pengujian terhadap normalitas data harus dilakukan agar asumsi dalam statistika parametric dapat terpenuhi. Pengujian normalitas data dapat dilakukan dengan melihat output chart yang dihasilkan berupa Normal P-P Plot of Regression Standardized Residual.

Cara lain yang diguanakan adalah Kolmogrof Smirnov (Sugiono, 2010). Dari table One Sample Kolmogrof Smirnov Test diperoleh angka probabilitas Asymp Sig. (2-tailed). Nilai ini dibandingkan dengan $0,05(\alpha=5 \%)$ untuk pengambilan keputusan :

1. Nilai Sig. Atau signifikansi atau nilai probabilitas $<0,05$, distribusi data tidak normal.

2. Nilai Sig. Atau signifikansi atau nilai probabilitas $>0,05$, distribusi data normal.

Tabel 3. Uji Normalitas

One-Sample Kolmogorov-Smirnov Test

\begin{tabular}{|c|c|c|}
\hline & & $\begin{array}{l}\text { Unstandardized } \\
\text { Predicted Value }\end{array}$ \\
\hline $\begin{array}{l}\mathrm{N} \\
\text { Normal Parameters } \\
\text { Most Extreme } \\
\text { Differences }\end{array}$ & $\begin{array}{l}\text { Mean } \\
\text { Std. Deviation } \\
\text { Absolute } \\
\text { Positive } \\
\text { Negative }\end{array}$ & $\begin{array}{r}72 \\
71.8991667 \\
136.00205721 \\
.118 \\
.118 \\
-.077\end{array}$ \\
\hline
\end{tabular}


Sumber : Output SPSS 20

\begin{tabular}{l|r|}
\hline $\begin{array}{l}\text { Kolmogorov-Smirnov Z } \\
\text { Asymp. Sig. (2-tailed) }\end{array}$ & 1.001 \\
\hline a. Test distribution is Normal. \\
b. Calculated from data.
\end{tabular}

Sesuai dengan output yang dihasilkan dari tabel 3 diatas maka kreteria yang digunakan yaitu Asymp. Sig (2-tailed) > dari tingkat alpha yang diterapkan sebesar 0,05 $(0.269>0.05)$, kemudian dapat disimpulkan bahwa data berasal dari populasi yang berdistribusi normal.

\section{Uji Multikolonieritas}

Menurut Ghozali (2012) uji multikolinearitas bertujuan untuk menguji apakah model regresi ditemukan adanya korelasi antar variabel bebas (independen). Model regresi yang baik seharusnya tidak terjadi korelasi antar variabel independen. Dalam penelitian ini uji mulkolinearitas yang digunakan adalah dengan melihat nilai Tolerance dan Inflation Factor (VIF).

Tabel 4. Uji Multikolonieritas Coefficients $^{\mathrm{a}}$

\begin{tabular}{|cl|r|r|}
\hline Model & \multicolumn{2}{|c|}{ Collinearity Statistics } \\
\cline { 3 - 4 } & & Tolerance & \multicolumn{1}{c|}{ VIF } \\
\hline \multirow{2}{*}{ H.MinyakBumi } & .206 & 4.848 \\
& H.Haphtha & .189 & 5.303 \\
H.Ethylene & .275 & 3.633 \\
& H.Polyethylene & .405 & 2.467 \\
1 & .336 & 2.977 \\
H.EthyleneGlycol & .644 & 1.553 \\
H.PolyvinylChloride & .208 & 4.806 \\
H.Propylene & .251 & 3.982 \\
H.Polypropylene & \multicolumn{2}{|c}{} \\
\multicolumn{2}{|c}{ a. Dependent Variable: ROA }
\end{tabular}

Sumber : Output SPSS 20

Hasil uji multikolonieritas dari tabel 4 bahwa nilai cut off yang umum dipakai dalam menunjukkan adanya multikolonieritas adalah VIF < 10 atau sama dengan nilai tolerances $>0,10$ (Ghozali, 2012). Berdasarkan hasil tabel 4 di atas dengan variabel dependen yaitu Return On Assetsmenunjukkan bahwa variabel independen dengan angka Variance Inflation Factor (VIF) di bawah 10 dan nilai tolerance lebih besar dari 0,10. Dengan demikian dapat disimpulkan bahwa tidak ada multikolonieritas antara variabel independen dalam model regresi.

\section{Uji Autokorelasi}

Autokorelasi adalah keadaan dimana pada model regresi ada korelasi atara residual pada periode $t$ dengan residual pada periode sebelumnya ( $t-1)$. Model regresi yang baik adalah yang tidak terdapat masalah autokorelasi. Metode pengujian menggunakan uji Durbin-Watson (DW test). 
Tabel 5. Uji Autokorelasi

Model Summaryb

\begin{tabular}{|l|r|r|r|r|r|}
\hline Model & R & R Square & $\begin{array}{c}\text { Adjusted R } \\
\text { Square }\end{array}$ & $\begin{array}{c}\text { Std. Error of the } \\
\text { Estimate }\end{array}$ & Durbin-Watson \\
\hline 1 & $.478^{\mathrm{a}}$ & .229 & .131 & 265.03824 & 2.150 \\
\hline
\end{tabular}

a. Predictors: (Constant), H.Polypropylene, H.Polyethylene, H.PolyvinylChloride,

H.Ethylene, H.EthyleneGlycol, H.MinyakBumi, H.Propylene, H.Haphtha

b. Dependent Variable: ROA

Sumber : Output SPSS 20

Hasil output SPSS 20 dari Tabel 5 di atas dapat diketahui bahwa nilai DurbinWatson sebesar 2,150. Pada taraf signifikan 5\% nilai DU dan DL dapat diperoleh dari tabel statistik Durbin Watson. Dengan $\mathrm{n}=72$ dan $\mathrm{k}=8$ didapat nilai $\mathrm{DL}=1,3715$ dan $\mathrm{DU}=$ 1,8706. Jadi nilai 4-DL $=(4-1,3715)=2,6285$ dan $4-\mathrm{DU}=(4-1,8706)=2,1294$. Karena nilai 4-DU $<$ DW $<4$-DL atau 2,1294 $<2,150<2,6285$, berarti tidak terdapat autokorelasi. (Ghozali 2012).

\section{Uji Heterokedastisitas}

Bertujuan menguji apakah dalam model regresi terjadi ketidaksamaan variance dari residual dari satu pengamatan ke pengamatan lain. Jika variance dari suatu pengamatan kepengamatan lain tetap, maka disebut homokedastisitas dan jika varians berbeda, disebut heterokedastisitas. Model regresi yang baik adalah tidak terjadi heterokedastisitas (Ghozali, 2012). Cara untuk mendeteksi ada atau tidaknya heterokedastisitas dapat melihat grafik scatterplot.

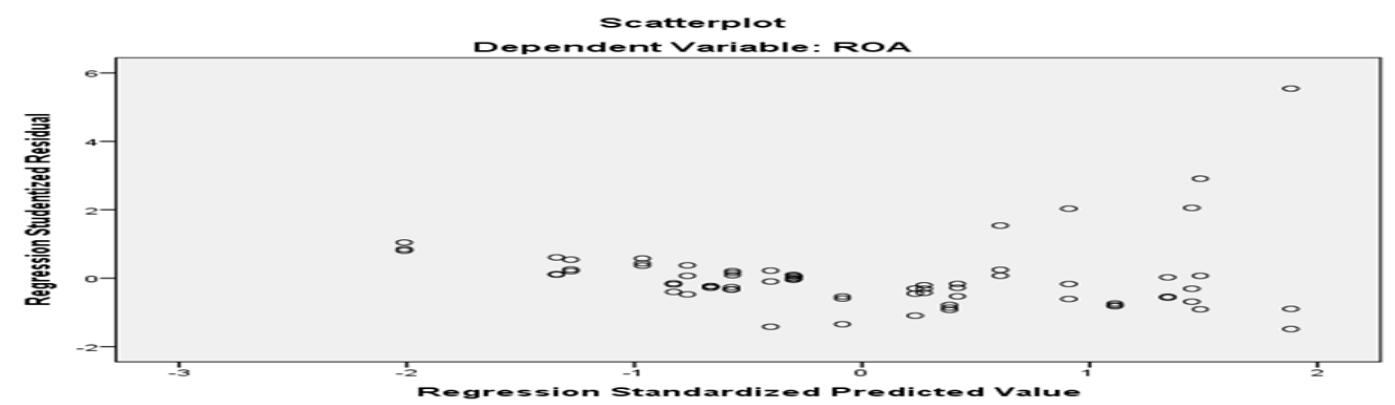

Sumber : Output SPSS 20

\section{Grafik 1.Grafik Scatterplot}

Grafik scatterplot diatas terlihat titik menyebar secara acak, tidak membentuk sebuah pola tertentu yang jelas, serta tersebar baik di atas maupun di bawah angka 0 padadependen variabel (Y). Maka hal ini menunjukkan tidak terjadi heteroskedastisitas pada dependen variabel (Y) dan tidak terjadi heteroskedastisitas pada model regresi.

\section{Analisis Data}

Tabel 6 : Hasil Pengujian Pengaruh Harga Minyak Bumi dan Harga Bahan Baku Plastik Terhadap Return On Asset Pada Perusahaan Penghasil Bahan Baku Plastik 


\begin{tabular}{|c|c|c|c|}
\hline Variabel & B & $\mathrm{t}$ & Hasil \\
\hline (Constant) & 97,867 & 3,026 &, 004 \\
\hline H.MinyakBumi & $-5,130$ & $-1,110$ & ,271 (-) Tidak Signifikan \\
\hline H.Naphtha & 8,711 & 1,690 & ,096 (+) Tidak Signifikan \\
\hline H.Ethylene & $-12,562$ & $-3,001$ & ,004 (-) Signifikan \\
\hline H.Polyethylene & 2,760 &, 519 & ,605 (+) Tidak Signifikan \\
\hline H.EthyleneGlycol & $-9,772$ & $-2,469$ & ,016 (-) Signifikan \\
\hline H.PolyvinylChloride & 3,779 & 1,076 & ,286 (+) Tidak Signifikan \\
\hline H.Propylene & 3,850 &, 770 & ,444 (+) Tidak Signifikan \\
\hline H.Polypropylene & 9,823 & 1,342 &, $184(+)$ Tidak Signifikan \\
\hline R Square &, 229 & & \\
\hline F Hitung & & 2,337 & 0,029 \\
\hline
\end{tabular}

Sumber : Hasil Pengolahan Data Penelitian (2016)

Pengaruh Harga Minyak Bumi, Harga Naphtha, Harga Ethylene, Harga Polyethylene, Harga Ethylene Glycol, Harga Polyvinyl Chloride, Harga Propylene dan Harga Polyproylene terhadap ROASecara Simultan.

Hasil analisis secara simultan (Uji F) dari tabel 6 diatas, diketahui $F$ tabel $=2,09$ dan berdasarkan nilai $\mathrm{F}$ hitung $=2,337$, karena nilai $\mathrm{F}$ hitung $(2,337)>\mathrm{F}$ tabel $(2,09)$ dan nilai signifikasinya $0,029<0,05$ maka dapat disimpulkan variabel Harga Minyak Bumi, Harga Naphtha, Harga Ethylene, Harga Polyethylene, Harga Ethylene Glycol, Harga Polyvinyl Chloride, Harga Propylene dan Harga Polyproylene berpengaruh secara simultan (bersama-sama) terhadap Return On Asset pada tingkat signifikan $\alpha=0,05$, sehingga secara keseluruhan Harga Minyak Bumi, Harga Naphtha, Harga Ethylene, Harga Polyethylene, Harga Ethylene Glycol, Harga Polyvinyl Chloride, Harga Propylene dan Harga Polyproylene dapat dijadikan pedoman dalam menentukan naik turunnya Return On Asset Pada Perusahaan Penghasil Bahan Baku Plastik.

Penelitian ini membuktikan bahwa hasil pengujian variabel independen Harga Minyak Bumi, Harga Naphtha, Harga Ethylene, Harga Polyethylene, Harga Ethylene Glycol, Harga Polyvinyl Chloride, Harga Propylene dan Harga Polyproylene terhadap ROA menunjukan bahwa terdapat pengaruh yang signifikan antara variabel independen terhadap variabel dependen. Hipotesis pada penelitian ini diterima, hal ini menyatakan bahwa perusahaan Perusahaan Penghasil Bahan Baku Plastik mampu mengelola asetnya secara efisien sehingga dapat meningkatkan kinerja keuangan perusahaan.

Pengaruh Besarnya Koefisien Determinasi variabel Harga Minyak Bumi, Harga Naphtha, Harga Ethylene, Harga Polyethylene, Harga Ethylene Glycol, Harga Polyvinyl Chloride, Harga Propylene dan Harga Polyproylene terhadap ROA.

Analisis uji koefisien determinasi $\left(\mathrm{R}^{2}\right)$ dari tabel 6 diatas menjelaskan bahwa nilai koefisien determinasi $\left(\mathrm{R}^{2}\right)$ dilihat bahwa hubungan antara variabel Harga Minyak Bumi, Harga Naphtha, Harga Ethylene, Harga Polyethylene, Harga Ethylene Glycol, Harga Polyvinyl Chloride, Harga Propylene dan Harga Polyproylene terhadap ROA pada perusahaan Penghasil Bahan Baku Plastik adalah sebesar $\mathrm{R}^{2}=0,229$ berarti 22,9\% variabel Harga Minyak Bumi, Harga Naphtha, Harga Ethylene, Harga Polyethylene, Harga Ethylene Glycol, Harga Polyvinyl Chloride, Harga Propylene dan Harga Polyproylene dipengaruhi oleh variabel ROA, sedangkan sisanya sebesar $771 \%$ dipengaruhi oleh faktorfaktor lain diluar variabel penelitian ini. 
Berdasarkan hasil dari tabel 6 diketahui bahwa nilai konstanta persamaan regresi berganda adalah 97.867, koefisien regresi Harga Minyak Bumi sebesar -5,130, koefisien regresi Harga Naphtha 8,711, koefisien regresi Harga Ethylene -12,562, koefisien regresi Harga Polyethylene 2,760, koefisien regresi Harga Ethylene Glycol -9,772, koefisien regresi Harga Polyvinyl Chloride 3,779, koefisien regresi Harga Propylene 3,850, koefisien regresi Harga Polyproylene 9,823. Jika dimasukan kedalam persamaan regresi berganda maka persamaan regresi berganda menjadi :

ROA $=97.867$ - 5,130 H.Minyak Bumi + 8,711 H.Naphtha - 12,562 H. Ethylene + 2,760 H.Polyethylene - 9,772 H.Ethylene Glycol + 3,779 H. Polyvinyl Chloride $+3,850$ H.Propylene + 9,823 H. Polyproylene

Persamaan regresi diatas menjelaskan bahwa :

1. Pada saat variabel independen Harga Minyak Bumi, Harga Naphtha, Harga Ethylene, Harga Polyethylene, Harga Ethylene Glycol, Harga Polyvinyl Chloride, Harga Propylene dan Harga Polyproylene bernilai 0 maka nilai Growth ROA adalah sebesar 97.867. Nilai ini memiliki arti bahwa Growth ROA pada perusahaan penghasil bahan baku plastik di Indonesia sudah baik karena standard ROA menurut Bank Indonesia No.6/9/PBI/2004 adalah minimal 1,5\%.

2. Jika ditingkatkan variabel Growth Harga Minyak Bumi sebesar satu satuan maka variabel Growth ROA akan menurun sebesar 5,130 satuan, dengan signifikasi 0,271 > 0,05 .

3. Jika ditingkatkan variabel Growth Harga Naphtha sebesar satu satuan maka variabel Growth ROA akan meningkat sebesar 8,711 satuan, dengan signifikasi 0,096>0,05

4. Jika ditingkatkan variabel Growth Harga Ethylene sebesar satu satuan maka variabel Growth ROA akan menurun sebesar 12,562 satuan, dengan signifikasi 0,004 < 0,05.

5. Jika ditingkatkan variabel Growth Harga Polyethylene sebesar satu satuan maka variabel Growth ROA akan meningkat sebesar 2,760 satuan, dengan signifikasi 0,605 > 0,05 .

6. Jika ditingkatkan variabel Growth Harga Ethylene Glycol sebesar satu satuan maka variabel Growth ROA akan menurun sebesar 9,722 satuan, dengan signifikasi 0,016 < 0,05 .

7. Jika ditingkatkan variabel Growth Harga Polyvinyl Chloride sebesar satu satuan maka variabel Growth ROA akan meningkat sebesar 3,779 satuan, dengan signifikasi 0,286 > 0,05 .

8. Jika ditingkatkan variabel Growth Harga Propylene sebesar satu satuan maka variabel Growth ROA akan meningkat sebesar 3,850 satuan, dengan signifikasi 0,444 > 0,05.

9. Jika ditingkatkan variabel Growth Harga Polypropylene sebesar satu satuan maka variabel Growth ROA akan meningkat sebesar 9,823 satuan, dengan signifikasi 0,184 > 0,05 . 


\section{PEMBAHASAN}

Pengaruh Harga Minyak Bumi, Harga Naphtha, Harga Ethylene, Harga Polyethylene, Harga Ethylene Glycol, Harga Polyvinyl Chloride, Harga Propylene dan Harga Polyproylene terhadap ROA secara parsial

H1 :Hasil pengujian hipotesis pertama menunjukkan bahwa harga minyak bumi $\left(\mathrm{X}_{1}\right)$ memiliki hubungan negatif dan tidak memiliki pengaruh signifikanterhadap Return On Assets(Y). Hasil temuan ini menolak penelitian Xu (2015), Basha (2014) meneliti tentang Harga Minyak Terhadap hasilnya berbeda yaitu hubungan Harga Minyak Terhadap Return On Assets berpengaruh positif signifikan.

Hasil penelitian menunjukkan bahwa fluktuasi harga minyak bumi tidak berpengaruh terhadap Return On Assets, hal ini disebabkan sekitar 40\% kebutuhan minyak metah di Indonesia masih berasal dari Inpor atau 350.000bph dari total 1 juta barel perhari (Hardidi, 2016) kebutuhan $40 \%$ minyak mentah tersebut berarti dengan menambah kapasitas produksi juga akan menambah kebutuhan minyak bumi sebagai Input vital dalam proses produksi industri, terutama untuk menghasilkan listrik, menjalankan mesin produksi dan untuk mengangkut hasil produksi, sehingga biaya produksi pun akan bertambah. Jika biaya produksi bertambah akan berdampak pada penurunan Net Income.

H2 : Hasil pengujian hipotesis menunjukkan bahwa Harga Naphtha $\left(\mathrm{X}_{2}\right)$ memiliki hubungan positifdan tidak memiliki pengaruh signifikanterhadap Return On Asset(Y).Hasil dari penelitian ini tidak sejalan dengan penelitian sebelumnya yaitu Ray (2014), Chiranjeev(2010), Kwon (2016) meneliti tentang Harga Naphtha Terhadap Return On Assets Industri Plastik hasilnya berbeda yaitu hubungan Harga NaphthaReturn On Assets berpengaruh positif signifikan.

Hasil penelitian menunjukkan fluktuasi Harga Naphtha tidak berpengaruh terhadap Return On Assets, dikarenakan Naphtha adalah bahan baku utama dalam Industri Petrokimia terutama sebagai bahan baku utama untuk menghasilkan plastik yang awal mulanya berasal dari minyak bumi dan naphtha sebagai turunan langsung dan dari Naphtha yang nantinya akan menghasilkan Ethylene, Propylene dan lainnya. Harga Naphtha sangat tergantung dari fluktuasi harga Minyak Bumi. Jika harga minyak bumi naik harga naphtha juga akan naik begitu juga sebaliknya dan masih tergantung akan impor minyak bumi, oleh karena itu harga naphtha memiliki hubungan positif namun tidak memiliki pengaruh signifikanterhadap Return On Assets.

H3 : Hasil pengujian hipotesis menunjukkan bahwa Harga Ethylene $\left(\mathrm{X}_{3}\right)$ memilikihubungan negatif dan memiliki pengaruh signifikan terhadap Return On Asset (Y). Hasil dari penelitian ini tidak sejalan dengan penelitian sebelumnya yaitu Ray (2014) meneliti Harga Ethylene Terhadap Return On Assets Industri Plastik hasilnya berbeda yaitu Harga Ethylene Terhadap Return On Assets berpengaruh positif signifikan.

Hasil penelitian menunjukkan bahwa fluktuasi Harga Ethylene berpengaruh terhadap Return On Assets, hal ini disebabkan Ethylene merupakan bahan baku penting dalam industri petrokimia dan turunanya plastik. Sekitar 130 juta ton Ethylene diproses di seluruh dunia pada tahun 2013. aplikasi langsungnya digunakan untuk produksi plastik. Kapasitas 
produksi Ethylene yang bertambah dari 600KTA ke 860KTA di 2015 membuat TPIA sebagai satu-satunya perusahaan yang memproduksi Ethylene di Indonesia menjadi perusahaan terbesar ke 5 di Asia Tenggara yang memproduksi polyolefins (TPIA, 2015). Dengan bertambahnya kapasitas prosuksi Ethylene dari 2013 ke 2015, menunjukan bahwa dari aset yang dipergunakan memproduksi Ethylene yang akan berpengaruh terhadap Net Income yang didapatkan, terntunya akan mempengaruhi Return On Assets.

H4 : Hasil pengujian hipotesis menunjukkan bahwa Harga Polyethylene $\left(\mathrm{X}_{4}\right)$ memilikihubungan positif dan tidak memiliki pengaruh signifikan terhadap Return On Asset (Y). Hasil dari penelitian ini tidak sejalan dengan penelitian sebelumnya yaitu Titov (2014), Malikane (2000) dan Koplan (2005) meneliti tentang Harga PolyethyleneTerhadap Return On Assets Industri Plastik tetapi hasilnya berbeda yaitu hubungan Harga PolyethyleneTerhadap Return On Assets berpengaruh positif signifikan.

Hasil penelitian menunjukkan bahwa fluktuasiHarga Polyethylenetidak berpengaruh terhadap Return On Assetshal ini dikarenakanseiring merosotnya harga naphtha, harga polyethylene ikut turun yang sampai sekarang yang masih bergantung oleh impor dari luar negeri. Karena produksi Polyethylene di Indonesia masih tergantung dengan bahan baku Impor, dan Harga Polyethylene pada umumnya mengikuti tren harga minyak bumi dan bervariasi sesuai kondisi pasar minyak bumi.

H5 : Hasil pengujian hipotesis menunjukkan bahwa Harga Ethylene Glycol( $\left.\mathrm{X}_{5}\right)$ memilikihubungan negatif dan memiliki pengaruh signifikan terhadap Return On Asset (Y). Hasil dari penelitian ini sejalan dengan penelitian sebelumnya yaituChatterjee (2011) juga meneliti tentang Harga Ethylene GlycolTerhadap Return On Assets Industri Plastik hasilnya sama yaitu hubungan Harga Ethylene Glycol Terhadap Return On Assets berpengaruh negatif signifikan dikarenakan motode efisiensi dan penggunaan biaya yang efektif.

Hasil penelitian menunjukkan bahwa fluktuasiHarga Ethylene Glycol berpengaruh terhadap Return On Assets, hal ini dikarenakanEthylene Glycol digunakan sebagai bahan baku Botol minuman, stoples selai kacang, film plastik, kemasan microwave yang di Indonesia sangat tergantung pada AMFG yang dimasukan sebagai objek yang memproduksi Ethylene Glycol.

H6 : Hasil pengujian hipotesis menunjukkan bahwa Harga polyvinyl chloride $\left(\mathrm{X}_{6}\right)$ memilikihubungan positif dan tidak memiliki pengaruh signifikan terhadap Return On Asset (Y). Hasil dari penelitian ini tidak sejalan dengan penelitian sebelumnya yaituMalikane (2000) juga meneliti tentang Harga PVC Terhadap Return On Assets Industri Plastik yaitu hubungan Harga Polyethylene, Harga PVC Terhadap Return On Assets berpengaruh positif signifikan.

Hasil penelitian menunjukkan bahwa fluktuasiHarga polyvinyl chloridetidakberpengaruh terhadap Return On Assets, hal ini dikarenakanIndustri PVC memiliki ketergantungan pasokan ethylene pada pasar internasional karena sebagian besar kebutuhannya saat ini masih diimpor.

H7 : Hasil pengujian hipotesis menunjukkan bahwa Harga Propylene $\left(\mathrm{X}_{7}\right)$ memilikihubungan positif dan tidak memiliki pengaruh signifikan terhadap Return On 
Asset (Y). Hasil dari penelitian ini tidak sejalan dengan penelitian sebelumnya yaituTitov (2014) juga meneliti tentang Harga PropyleneTerhadap Return On Assets Industri Plastik hasilnya berbeda yaitu hubungan Harga PropyleneTerhadap Return On Assets berpengaruh positif signifikan

Hasil penelitian menunjukkan bahwa fluktuasiHarga Propylene tidakberpengaruh terhadap Return On Assets, hal ini dikarenakanbahan bakunya adalah naphtha di indonesia masih bergantung kebutuhannya saat ini masih diimpor.

H8 : Hasil pengujian hipotesis menunjukkan bahwa Harga Polyproylene ( $\left.\mathrm{X}_{8}\right)$ memilikihubungan positif dan tidak memiliki pengaruh signifikan terhadap Return On Asset (Y).Hasil dari penelitian ini tidak sejalan dengan penelitian sebelumnya yaituTitov (2014) harga polypropyleneterhadap return on assets industri plastik berbeda yaitu hubungan harga propylene danharga polypropylene terhadap return on assets berpengaruh positif signifikan.

Hasil penelitian menunjukkan bahwa fluktuasiHarga polypropylenetidakberpengaruh terhadap Return On Assets, hal ini dikarenakanbahan baku dari Polypropylene adalah Propylene yang berasal dari Naphtha di Indonesia bergantung kebutuhannya saat dari impor luar negeri

\section{KESIMPULAN}

Berdasarkan hasil penelitian dan pembahasan, maka dalam penelitian ini dapat disimpulkan sebagai berikut :

1. Pertumbuhan Harga Minyak Bumi secara parsial berpengaruh negatif dan tidak signifikan terhadap Return On Assets.

2. Pertumbuhan Harga Naphtha secara parsial berpengaruh positif dan tidak signifikan terhadap Return On Assets.

3. Pertumbuhan Harga Ethylene secara parsial berpengaruh negatif dan signifikan terhadap Return On Assets.

4. Pertumbuhan Harga Polyethylene secara parsial berpengaruh positif dan tidak signifikan terhadap Return On Assets.

5. Pertumbuhan Harga Ethylene Glycol secara parsial berpengaruh negatif dan signifikan terhadap Return On Assets.

6. Pertumbuhan Harga Polyvinyl Chloride secara parsial berpengaruh positif dan tidak signifikan terhadap Return On Assets.

7. Pertumbuhan Harga Propylene secara parsial berpengaruh positif dan tidak signifikan terhadap Return On Assets.

8. Pertumbuhan Harga Polyproylene secara parsial berpengaruh positif dan tidak signifikan terhadap Return On Assets.

\section{SARAN}

Dengan berbagai telaah dan analisa yang dilakukan berdasarkan keterbatasanketerbatasan penelitian, maka dapat dberikan saran bagi peneliti selanjutnya yaitu sebagai berikut : 
1. Para investor baiknya lebih berhati-hati dalam menanamkan sahamnya karena bukan hanya melihat pergerakan harga minyak bumi saja dan terus bisa menyimpulkan bahwa dengan rendahnya harga minyak bumi berarti laba yang didapatkan dari penjualan turunan yang berupa bahan baku plastik juga mengikuti mendapatkan keuntungan, ada faktor-faktor lain selain pertumbuhan harga bahan baku utamanya yang bisa memberikan gambaran profitabilitas perusahaan yaitu pertumbuhan PBD dan pertumbuhan kurs

2. Rasio Return On Asset yang tinggi dapat diasumsikan bahwa perusahaan dapat beroperasi secara efektif dan akan menjadi daya tarik bagi investor yang akan menanamkan sahamnya diperusahaan.

3. Sampel pada penelitian ini terbatas oleh tiga perusahaan penghasil bahan baku plastik di dalam negeri, untuk penelitian selanjutnya dapat menggunakan sampel dengan jumlah perusahaan dan data yang lebih banyak.

\section{DAFTAR PUSTAKA}

Alam, Syamsu . 2015. Pertamina Incar Sejumlah Lapangan Migas di Luar Negeri http://www.emaritim.com/2015/07/pertamina-incar-sejumlah-lapangan-migas.html

Aprilriana, Arrum Dyah. 2012.”Analisis Implementasi Kebijakan Insentif Pajak Penghasilan Untuk Industri Petrokimia Berbasis Migas Dalam Rangka Peningkatan Daya Saing Industri Petrokimia Nasional”. Skripsi. Program Studi Ekonomi, Fakultas Ekonomi Akuntansi. Universitas Indonesia. Depok

Aprillia, Ika. 2016. Akhir 2017 Harga Minyak Akan Rebound. http://ekonomi.kompas.com/read/2016/05/02/081700026/IEA.Akhir.2017.Harga.Min yak.akan.Rebound.

Aprilta, Fanny. 2011. "Analisis Dampak Fluktuasi Harga Minyak Dunia Terhadap Variabel Makroekonomi Dan kebijakan Subsidi di Indonesia 1980-2010” Skripsi. Program Studi Ekonomi, Fakultas Ilmu Ekonomi. Institut Pertanian Bogor. Bogor

Baird, Ronald. J.2006. Industrial Plastik The Goodheart. Willcox CompanyInc. New York.

Barlian, Inge. Sundjaja, Ridwan. 2003. Manajemen Keuangan I. Edisi Kelima. Literata Lintas Media. Jakarta

Basha, Mazen Hassan. 2014. "Impact of Increasing the Crude Oil Prices on the Financial Performance of Pharmaceutical Companies Operating in Jordan for the Period (20022011) A Case Study of Jordanian Al-Hikma Pharmaceutical Company" European Journal of Business and Management. ISSN 2222-1905 (Paper) ISSN 2222-2839 (Online) Vol.6, No.33, 2014.

Bayu, Akbar. 2015. Pentingnya Industri Plastik Dalam Negeri. http://www.republika.co.id/berita/ekonomi/makro/15/07/09/nr85w0-ini-pentingnyaindustri-plastik-dalam-negeri

BP Statistical. 2015. Minyak Bumi (petroleum) https://www.indonesia-investments.com/id/bisnis/komoditas/minyak-bumi/item267? Budiono, Fajar. 2015. Minyak Jatuh, Petrokimia Bisa Kempit Margin. 
http://industri.kontan.co.id/news/minyak-jatuh-petrokimia-bisa-kempit-margin

Ceresana. 2013. Market Study of Ethylene.

http://www.ceresana.com/en/market-studies/chemicals/ethylene/

Chatterjee, Kumar. Hall, Kelsey. Tell, Samuel. 2011. "Glycerol to Propylene Glycol" Journal of the American Oil Chemists Society. University of Pennsylvania. 80 (2) pp $189-192$

CHEJ. 2008. Pass Up the Poison Plastic. The PVC-Free Guide for Your Family and Home. Center For Health, Environment and Justice https://www.google.co.id/url?sa=t\&rct=j\&q=\&esrc=s\&source=web\&cd=2\&cad=rja \&uact $=8 \&$ ved $=0$ ahUKEwiwl7fx6vvVAhXEQ48KHQrAAMQFggwMAE\&url=http\%3A\%2F\%2Fwww.ejnet.org\%2Fplastics\%2F\&usg=AFQj CNErjxfvC_BX1Z79javSQ9RTFs2ufg

Chemorbis. 2016. Bagaimana pasar poliolefin akan menyambut tahun 2017? https://www.chemorbis.com/news/commonin/buyutec/678416.htm?year=2017\&mon th $=01 \&$ days $=02 \&$ title $=$ Bagaimana + pasar + poliolefin + akan + menyambut + tahun +2017 $+\&$ isflashhaber $=$ true \&template $=$ print Article.jsp

Chiranjeev. Rajneesh. 2010. "The price is right? Guidelines for pricing to enhance profitability”Business Horizons. Volume 54, Issue 6, November-December 2011, Pages 563-573

Cowley. P R. 1983. "Modelling the effect of buyer power on the margins of commodity plastics” Strategic Management Journal. Vol. 6 pp 213-222

Enggartiasto, Lukita. 2016.Menperin Desak Investasi Industri Petrokimia Tahun 2017.http://www.kemenperin.go.id/artikel/17005/Menperin-Desak-InvestasiIndustri-Petrokimia-Tahun-2017

Fahmi, Trham. 2013. Analisis Laporan Keuangan. Alfabeta. Bandung.

George, Antos, dan Abdullah. 2004 Catalytic Naphtha Reforming, Revised and Expanded. Second Edition Revised and Expanded

Ghozali, Imam. 2012. Aplikasi Analisis Multivariate Dengan Program SPSS. Badan Penerbit Universitas Diponegoro. Semarang.

Gujarati, Damodar. 2006. Dasar-dasar Ekonometrika. Erlangga. Jakarta.

Hanafi, Abdul. 2005. Analisa Laporan Keuangan. Edisi Kedua. Cetakan Pertama. BPFE. Yogyakarta

Hardidi, Rahmat. 2016. RI Impor Minyak Mentah 350.000 Barel/Hari dari Arab Hingga Nigeria https://finance.detik.com/energi/3229156/ri-impor-minyak-mentah-350000barelhari-dari-arab-hingga-nigeria

NCBI. 2016. Open Chemistry Databese Of Ethylene https://pubchem.ncbi.nlm.nih.gov/compound/Ethene\#section=Top

Indonesia Investasi. 2015. Minyak Bumi. https://www.indonesia-investments.com/id/bisnis/komoditas/minyak-bumi/item267

Jati, Yusuf Waluyo. 2016. Pertumbuhan Konsumsi Plastik. http://industri.bisnis.com/read/20160823/257/577692/tahun-ini-pertumbuhankonsumsi-plastik-bisa-di-bawah-target 
Jonan, Ignasius. 2016. Realisasi Harga Minyak Mentah Indonesia http://www.tribunnews.com/bisnis/2017/06/06/realisasi-harga-minyak-mentahindonesia-periode-januari-mei-2017-di-bawah-usd-50barel

Joseph,P.H.Fan. 2000. "Price uncertainty and vertical integration: an examination of petrochemical firms "Journal Of Corporate Financial 6 (2000). Pages 345 - 376

Kasmir. 2010. Pengantar Manajemen Keuangan. Kencana Prenada Media Group. Jakarta.

Kent, Robin. 2012. Periodic Table of

Polymershttp://www.pcn.org/Technical\%20Notes\%20\%20Periodic\%20Table\%20of\%20Pol ymers.html.

Kementrian Perindustrian Republik Indonesia.2014 Profil Industri Petrokimia Hulu https://www.google.co.id/url?sa=t\&rct=j\&q=\&esrc=s\&source=web\&cd=5\&cad=rja \&uact=8\&ved=0ahUKEwiVyZL5yeTPAhUMto8KHcGdAQAQFggxMAQ\&url=htt p\%3A\%2F\%2Fwww.kemenperin.go.id\%2Fdownload\%2F7545\%2FProfil-IndustriPetrokimia Hulu\&usg=AFQjCNFBzweCdIsLxXr8N1ASFXUnhDKn0w

Kementrian Perdagagnan. 2015. Laporan Akhir Kajian Kebijakan Harga. Puska Dagri. BP2KPhttp://bppp.kemendag.go.id/media_content/2017/08/Kajian_Kebijakan_Harga .pdf

Kohli, Chiranjeev. Suri, Rajneesh. 2010. "The price is right? Guidelines for pricing to enhance profitability”. Business Horizons. Volume 54, Issue 6, NovemberDecember 2011, Pages 563-573

Koplan, Stephen. Tanner, Deanna. 2005. "Polyethylene Terephthalate (PET) Resin From India, Indonesia, and Thailand Investigations "The Daily Journal of the United States Goverment. Publication 3769 Nos. 701-TA-439 and 731-TA-1077, 1078 and 1080 (Final) pp 24118-24119

Kuncoro, Mudrajad. 2003. Metode Riset untuk Bisnis dan Ekonomi. Erlangga. Jakarta.

Kwon, Hweeung. Lyu, Byeonggil dan Tak, Kyungjae. 2016. "Optimization of naphtha purchase price using a price prediction model". International Journal of Computer Applications in Chemical Engineering. Volume 84, 4 January 2016, Pages 226-236.

Lisnawati. 2009. "Pusat Penelitian Badan Keahlian DPR RI" ISSN 2088-2351 Vol VIII. No. 02/II/P3DI/Januari/2016

LPS. 2015. Ringkasan Perekonomian dan Perbankan http://www.lps.go.id/documents/830952/0/Laporan+Perekonomian+dan+Perbankan+ -+Januari+2015.pdf/09eff83c-ea63-44ac-aa1a-a6787bc097c9

Mamduh, M. 2008. Manajemen Keuangan. Edisi 1, BPFE, Yogyakarta

Masih, Mansur, Algahtani, Ibrahim, De Mello, Lurion. 2014. "Price dynamics of crude oil and the regional ethylene market" Energy Economics 32 pp 1435 - 1444

Malikane, Chris, Simon dan Ndiadivha. 2000. "Competition and Market Structure In The Plastics Sector : A Preliminary Analysis”South African Journal of Economics.Department ofEconomics. Vol. 66 No.4.

Misaryo, Suhat. 2015. Perusahaan Akan Untung Jika Harga Minyak Dunia Turunhttp://industri.kontan.co.id/news/minyak-jatuh-petrokimia-bisa-kempit-margin 
Mulyani, Sri. 2009. Basis Harga Minyak Mentah

Indonesia.http://www.setneg.go.id/index.php?option=com_content\&task=view\&id=1 666

Narimawati, Umi. 2010. Penulisan Karya Ilmiah. Genesis. Jakarta.

Nizar, Afdi.2012. "DampakFluktuasi Harga MinyakTerhadap Perekonomian Indonesia".Jurnal Ilmiah Litbang Perdagangan,Vol.6No.2.

NIOSH. 1993. Niosh Manual of Analytical Methods (NMAM). Fouth Edition https://www.cdc.gov/niosh/topics/ethylene-glycol/default.html

Pandjaitan M. 2006. Industri Petrokimia dan DampakLingkungannya. Gajah Mada University Press. Yogyakarta.

Pospector. Propylene (PP) Plastic

https://pubchem.ncbi.nlm.nih.gov/compound/Propene

.Polypropylene (PP) Plastic

https://plastics.ulprospector.com/generics/39/polypropylene-pp

Prawira, Kadek Yuli. 2015. Analisis Pengaruh Perubahan Uang Beredar, BI Rate, Kurs Rupiah dan Harga Minyak Mentah Indonesia Terhadap Perubahan Indeks Harga Saham Gabungan di Bursa Efek Indonesia Tahun 2008-2015. Tesis. Program Studi Pascasarjana. Fakultas Magister Manajemen. Universitas Mercubuana. Jakarta.

PT. Asahimas Group Tbk (AMFG).2016. Annual Report

PT. Chandra Asri Petrochemical Tbk (TPIA).2016. Annual Report

PT. Lotte Chemical Titan Tbk (FPNI).2016. Annual Report

Purnowo, Rudi . 2009. "Pengaruh Perubahan Harga Minyak Internasional dan Kbijakan Moneter di Indonesia Menggunakan Dynamic Stochastic General Equilibrium". Disertasi. Program Studi Pascasarjana Ekonomi, Fakultas Ekonomi. Universitas Indonesia. Depok.

Rachmat. 2016. Pertamina Ungkap Untung Rugi Indonesia Ikut OPEC http://m.viva.co.id/berita/bisnis/854864-pertamina-ungkap-untung-rugi-indonesiaikut-opec

Ray, Saon. Goldar, Amrita dan Saluja, Swati. 2014 "Feedstock for the Petrochemical Industry" Indian Council For Research On International Economic Relation. Working Paper 271.

Riduwan. 2007. Rumus dan Data Dalam Analisis Statistika. Alfabeta. Bandung.

Riyanto, Bambang. 2001. Dasar-dasar Pembelanjaan Perusahaan. BPFE. Yogyakarta

Rosadi, Dedi. 2011. Ekonometrika dan Analisis Runtun Waktu Terapan. Andi Offset. Yogyakarta

Rustam Agus. 2015. Menakar Kinerja TPIA http://market.bisnis.com/read/20160919/192/585070/menakar-kinerja-tpia

Said, Sudirman. 2015. Renstra KESDM 2015-2019 https://www.esdm.go.id/assets/media/content/Renstra_KESDM.pdf

Setiawan. 2015. Teknik Praktis Analisis Data Penelitian Sosial dan Bisnis dengan SPSS. CV Andi Offset (Penerbit Andi). Yogyakarta.

Shreve. 2014. Chemical Process Industries. International Student Edition. Second Edition. 
Stevens, Malcolm. 2001. Polymer Chemistry: An Introduction. Saduran Lis Sopyan. Cetakan Pertama. PT Pradnya Paramita. Jakarta

Soehartono, Irawan. 2012. Prosedur Penelitian Sosial. PT. Remaja Rosda Karya. Bandung.

Sudana, I Made. 2011. Manajemen Keuangan Perusahaan. Erlangga. Jakarta.

Sudarmo. 2013. Kimia Untuk SMA/MA Kelas XI, Kelompok Peminatan Matematika dan Ilmu Alam. Erlangga. Jakarta

Sugiono. 2010. Metode Penelitian Pendidikan. Alfabeta. Bandung. 2012. Metode Penelitian Kuantitatif. Alfabeta. Bandung.

Supranto. Nanda, Limakrisna. 2012. Petunjuk Praktis Penelitian Ilmiah untuk Menyusun Skripsi, Tesis dan Disertasi. Mitra Wacana Media. Jakarta

Survey Sampling International. 2016. Plastic Indonesia https://www.surveysampling.com/search/?cx=Survey+Sampling+International\&ie=U TF-8\&q=plastic+indonesia

Sofia. Helena Veiga. 2010. "Risk factors in oil and gas industry returns" International evidence. International Journal Of Energy Economic 33 (2011).Page 525 - 542

Syamsuddin, Lukman. 2009. Manajemen Keuangan Perusahaan. Raja Grafindo Persada. Jakarta.

Titov, Mariya, Ydriss. 2014. "Price Dynamics of Propylene andEthylene in the United States"The Journal of Energy and Development Vol. 39, No. 1/2 (Autumn, 2013 and Spring, 2014), pp. 207-217

Undang-undang No. 22. 2001 Tentang Minyak Bumi dan Gashttp://www.sjdih.depkeu.go.id/fullText/2001/22TAHUN2001UU.html

Van Horne. Wachowicz, John M dan C, James. 2005. Prinsip-prinsip Manajemen Keuangan. Edisi Kedua Belas. Salemba Empat. Jakarta

Veithzal.2007.BankAndFinancialManagement:ConventionalAndSyariaSystem.PTRajaGraf indoPersada. Jakarta.

Victor. 2012. Sejarah dan Perkembangan Industri Plastik. http://repository.usu.ac.id/bitstream/handle/123456789/54084/Reference.pdf;jsessioni $\mathrm{d}=851 \mathrm{C} 2 \mathrm{~B} 724 \mathrm{E} 9489 \mathrm{FFC} 3 \mathrm{~A} 55 \mathrm{CA} 974 \mathrm{~F} 5 \mathrm{FF} 9 \mathrm{E}$ ? sequence $=2$

Voulgaris, Fotini. Lemonakis, Christos. 2014. "Competitiveness and profitability, The case of chemicals, pharmaceuticals and plastics". The Journal of Economic Asymmetries. Volume 11, June 2014. ISSN : 1703-4949 pp 46-57

Wahana Komputer. 2014. Analisis Data Penelitian Dengan SPSS 20. Andi. Cetakan Pertama. Jakarta.

Wiratmaja, I Gusti Nyoman. 2016. ESDM Ubah Formula ICP dengan Skema Baru. http://eksplorasi.id/esdm-ubah-formula-icp-dengan-skema-baru/

Wattanatorn, Woraphon. Kanchanapoom Termkiat. 2012. "Oil Prices and Profitability Performance: Sector Analysis".Pacific Business Innovation and Technology Management. Journal. Prodecia Social and Behavioral Sciences 40 pp 763 - 767

World Oil Outlook. 2015. 
http://www.opec.org/opec_web/static_files_project/media/downloads/publications/W OO\%202015.pdf

Xu, Chengcheng. Xie, Bingqing. 2014. "The Impact Of Oil Price On Bank Profitability In Canada”Journal of Banking \& Fianence. Simon Fraser University. 16.6 pp 11731178

Yulianto, Agus. 2016. Prediksi Harga Minyak dan Gas Dunia 2016 dan Dampak untuk Indonesia.

http://www.republika.co.id/berita/jurnalisme-warga/wacana/16/10/09/oes13r396prediksi-harga-minyak-dan-gas-dunia-2017-dan-dampak-untuk-indonesia-1 